ГАЛУЗЕВИЙ АСПЕКТ РОЗВИТКУ НАЦІОНАЛЬНОГО ГОСПОДАРСТВА

УДК 339.564:338.433

DOI: 10.25140/2411-5215-2021-2(26)-65-74

Люба Турчин

\title{
ПОТЕНЦАЛ ЕКСПОРТНОГО МАРКЕТИНГУ В АГРАРНОМУ СЕКТОРІ УКРАЇНИ
}

\author{
Liuba Turchyn \\ POTENTIAL OF EXPORT MARKETING \\ IN THE AGRICULTURAL SECTOR OF UKRAINE
}

У статті досліджено відмінності між внутрішнім і міжнародним маркетингом. Встановлено місие експортного маркетингу в масштабах маркетингової діяльності. Визначено зміст експортного маркетингу, а також детально розглянуто його специфіку для агарних підприємств. На основі запропонованих показників (динаміка обсягів українського експорту; вартісна структура експорту аграрних підприємств; динаміка товарної структури експорту аграрних підприємств; основні імпортери вітчизняної продукції аграрних підприємств) проаналізовано сучасний стан потенціалу експортного маркетингу в аграрному секторі України. Вказано на необхідність розробки комплексу експортного маркетингу аграрних підприємств з метою підвищення його потенціалу в аграрному секторі України.

Ключові слова: експортний маркетинг; потенціал експортного маркетингу; міжснародний маркетинг; експортний маркетинг аграрних підприємств.

Рис.: 5. Табл.: 1. Бібл.: 8 .

The article examines the differences between domestic and international marketing. The place of export marketing in the scale of marketing activity is established. The content of export marketing is determined, as well as its specifics for agar enterprises are considered in detail. Based on the proposed indicators (dynamics of Ukrainian exports; cost structure of exports of agricultural enterprises; dynamics of commodity structure of exports of agricultural enterprises; major importers of domestic products of agricultural enterprises), analyzed the current state of export marketing potential in the agricultural sector of Ukraine. The need to develop a complex of export marketing of agricultural enterprises in order to increase its potential in the agricultural sector of Ukraine.

Keywords: export marketing; potential of export marketing; international marketing; export marketing of agricultural enterprises.

Fig.: 5. Table: 1. References: 8.

JEL Classification: Q17

Постановка проблеми. Процес глобалізації, жорстка конкуренція іноземних організацій на внутрішньому ринку або розширення його меж змушує компанії виходити на зовнішній ринок. Найпростішою міжнародною операцією, з якої починають багато підприємств, $\epsilon$ експорт товарів або послуг. Зовнішньоекономічна діяльність вимагає від підприємців подолання певних труднощів, пов'язаних із пристосовуванням свого товару під споживчі потреби закордонних споживачів: зокрема необхідність знання іноземної мови, вивчення їхніх звичок i традицій. Це, у свою чергу, додає виробничій i збутовій діяльності підприємствам певної невизначеності, нестабільності (економічної, політичної), що відповідно пов'язано зі збільшенням витрат. Проте для вітчизняних підприємств вихід на міжнародну торговельну арену $є$ на сьогодні одним зі стратегічних завдань. Його вирішення безпосередньо залежить рівня потенціалу експортного маркетингу.

Україна зберігає провідні позиції у світі є третім найбільшим експортером зерна, виробляючи щорічно 90-100 млн тонн зернових культур. У структурі експорту сільське господарство також відіграє значну роль: у 2019 р. аграрні підприємства принесли Україні майже 40 \% валютної виручки, демонструючи стабільність протягом останніх трьох років. Отже, аграрний сектор може стати локомотивом розвитку економіки та дати поштовх розвитку іншим галузям, завдяки значному експортному потенціалу аграрних підприємств.

Аналіз останніх досліджень і публікацій. Значну увагу дослідженню експортного маркетингу в аграрному секторі приділено в наукових публікаціях учених Б. Г. Базилюка, О. А. Белевята, І. С. Воронецької, А. С. Гальчинського, Ю. С. Гудзинської, Г. С. Жуйкова, Г. М. Запші, С. М. Кваші, О. А. Корнієвського, Л. А. Нападовської, М. П. Сахацького, I. О. Соловйова та ін. [1-5]. Науковцями проаналізовано структуру експорту агропродовольчої продукції, перспективи його розвитку, визначено сучасний стан зовнішньої торгівлі України аграрною продукцією.

(C) Турчин Л. Я., 2021 
Виділення недосліджених частин загальної проблеми. Обговорення економічних вигід від збільшення експортних операцій аграрного сектору України не втрачає своєї актуальності. Проте питанню сучасного стану потенціалу експортного маркетингу в аграрному секторі України присвячено недостатньо уваги, що зумовлює тему дослідження.

Мета статті. Головною метою цієї роботи є аналіз сучасного стану потенціалу експортного маркетингу в аграрному секторі України.

Виклад основного матеріалу. Існують певні відмінності між внутрішнім і міжнародним маркетингом, які потребують більш детального вивчення. Різниця в підході в розробці маркетингової політики на внутрішньому і зовнішньому ринках полягає в тому, що на останньому зовнішні фактори більш непередбачувані, а правила гри більш неоднозначні, а часом і суперечливі.

Внутрішній маркетинг - маркетингові заходи, вироблені на внутрішньому ринку. Міжнародний маркетинг - заходи, які здійснюються за межами країни-виробника. Особливим різновидом міжнародного маркетингу є експортний маркетинг, який пов'язаний з реалізацією функцій і задач у сфері маркетингу підприємств та організацій у зв'язку з їхньою діяльністю на зовнішніх ринках збуту.

Експортний маркетинг - система дослідження, просування і реалізації продукції за межі національних кордонів, орієнтована на найбільш повне задоволення вимог іноземних споживачів. Компанії розглядають експортні поставки як серйозне джерело для отримання додаткового прибутку. Фірма розвиває двосторонні відносини із зарубіжними покупцями (імпортерами), вивчає потреби і запити потенційних споживачів. Тому продукція поставляється модернізована, більше адаптована під вимоги імпортерів. Експортний маркетинг - це початкова стадія виходу компаній на зовнішній ринок. 3 переходом від однієї стадії до іншої змінюються масштаби маркетингової діяльності, співвідношення яких представлено на рис. 1.

Ця схема відображає основні етапи розвитку міжнародного маркетингу та співвідношення їхніх масштабів: внутрішній - експортний - міжнародний - глобальний.

Ключовими правилом, яким необхідно володіти при виході підприємства на міжнародні ринки, $є$ застосування адаптованих під умови закордонного ринку методів та інструментів маркетингу. Те, що працює на внутрішньому ринку, є неефективним на міжнародному.

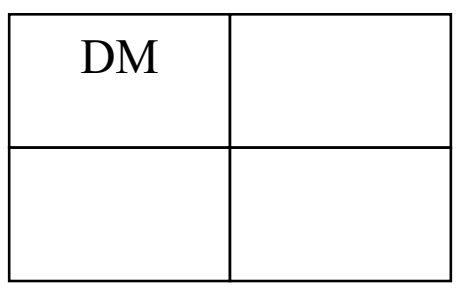

DM (Domestic Marketing) Внутрішній маркетинг

\begin{tabular}{|c|c|}
\hline $\mathrm{DM}$ & $\mathrm{IM}_{1}$ \\
\hline $\mathrm{DM}_{\mathrm{e}}$ & $\mathrm{IM}_{\mathrm{n}}$ \\
\hline
\end{tabular}

IM (International Marketing) Міжнародний маркетинг

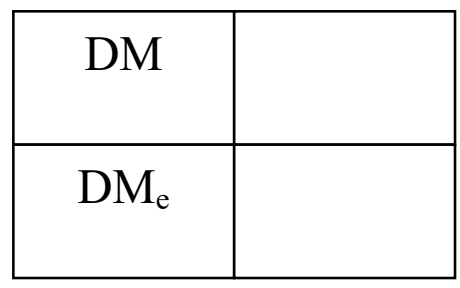

$\mathrm{DM}_{\mathrm{e}}$ (Domestic Export Marketing)

Експортний маркетинг

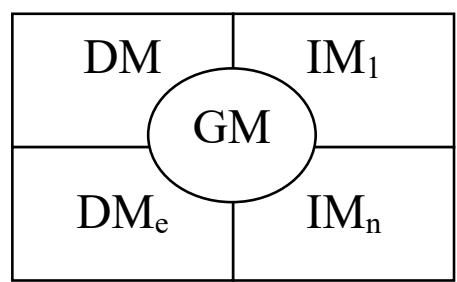

GM (Global Marketing) Глобальний маркетинг

Рис. 1. Місие експортного маркетингу в масштабах маркетингової діяльності 
ГАЛУЗЕВИЙ АСПЕКТ РОЗВИТКУ НАЦІОНАЛЬНОГО ГОСПОДАРСТВА

Експортний маркетинг більш праце- і капіталозатратний, оскільки виходячи на новий міжнародний ринок, виробник стикається з новим типом покупця, з нової правової атмосферою, регулювання якої може значно відрізнятися від звичного внутрішнього ринку. I навіть попри загальну тенденцію до глобальної уніфікації методів виробництва, регулювання, просування продукції, все ж експортний маркетинг на міжнародних ринках істотно відрізняється. Ці відмінності зумовлені такими зовнішніми факторами, які необхідно враховувати при розробці маркетингової програми на експорт.

1. Мова і релігія споживача. Підприємство-експортер (особливо виробник продуктів харчування) обов'язково повинен враховувати релігійні уподобання споживача (типовий приклад таких переваг - це халяль). Водночас часто милозвучність торгової марки відіграє критичну роль у виборі продукції - на полицях у магазинах практично неможливо зустріти складні назви брендів. Зазвичай усі найменування однаково легко звучать будь-якою мовою (за винятком азіатських брендів). Також варто враховувати, що важковимовні назви торгової марки унеможливлюють прочитання їх іноземцями, а отже, важко очікувати від споживача, що він буде купувати товар, не вміючи навіть вимовити і тим більше запам'ятати торгову марку.

2. Естетичні уявлення споживача. Часто особливості менталітету впливають на споживання того чи іншого продукту. Наприклад, у Китаї з білим кольором асоціюється траур, а з червоним - радість, тоді як в європейських культурах білий колір асоціюється 3 легкістю і чистотою. Це потрібно враховувати при оформленні зовнішнього вигляду продукції, що експортується. Строгий і лаконічний чорний або білий, який у західних культурах швидше асоціюється з продуктами преміального сегмента, викличуть здивування у азіатського споживача, який звик до золотисто-червоного оформлення дорогих продуктів. Звичайно, сьогодні глобалізація дозволяє жителям різних регіонів знайомитися 3 продуктами 3 далеких країн, змінює його звички і уявлення про продукти, але $\epsilon$ глибинні традиційні уявлення споживача, на зміну яких піде не одне десятиліття. Їх і треба брати до уваги при виборі стратегії входу на новий ринок.

3. Рівень втручання держави в діяльність ринку. Часто держава втручається в регулювання свого ринку, вводячи додаткові бар'єри для зовнішніх постачальників. Це можуть бути специфічні сертифікати, необхідні при ввезенні продукції, нові вимоги до продукції, що вже продається тощо.

4. Рівень технологічного і матеріального розвитку ринку. Розвинений як технологічно, так і матеріально ринок вимагає і технологічно розвиненого продукту. Дорогий продукт є сенс подавати на розвиненому в матеріальному плані ринку, там, де рівень ВВП на душу населення вище.

По суті, маркетингова діяльність на внутрішньому ринку не відрізняється від аналогічної. Функції, елементи комплексу маркетингу, розробка стратегій, сегментування і позиціонування, контроль маркетингової діяльності на зарубіжних ринках надають експортному маркетингу певні риси, які підприємства повинні враховувати при виході на зовнішній ринок. Зокрема, це:

- наявність достатніх внутрішніх ресурсів, виробничих потужностей для виробництва продукції на експорт;

- врахування економічних, політичних і культурних чинників зовнішнього ринку;

- адаптація маркетингової діяльності під умови міжнародних ринків і запити зарубіжних споживачів;

- більш послідовне та чітке дотримання принципів маркетингу, використання маркетингових прийомів, методів, процедур, ніж це потрібно на внутрішньому ринку;

- креативний підхід при використанні різних маркетингових процедур. 
Головна вимога експортного маркетингу є постійне оновлення продукції відповідно до мінливих вимог зарубіжних споживачів. Тому важливою категорією, що вивчається при виході компанії на зовнішній ринок, вважається життєвий цикл експортного товару. Слід враховувати, що час визнання товару в деяких зарубіжних країнах різне. Той же самий товар може перебувати на різних етапах життєвого циклу в окремих державах. Це відбувається під впливом таких факторів: рівень соціально-економічного розвитку країни; поточний рівень конкуренції; ступінь насиченості ринку товарами; особливості споживання товару; традиції, звичаї і менталітет споживачів. Тому при розробці комплексу експортного маркетингу необхідно знати, що на ринках розвинених країн життєвий цикл товару коротше, ніж на ринках, що розвиваються. Але має місце тенденція поступового вирівнювання і скорочення тривалості життєвого циклу для окремих країн. Дотримання принципів і методів експортного маркетингу дозволяє компаніям уникнути негативних наслідків і невдач у конкурентній боротьбі на міжнародних ринках. А також є запорукою ефективної діяльності та довготривалої присутності на зовнішньому ринку.

Використання маркетингу в сільському господарстві має свої особливості, пов'язані як зі специфікою сільськогосподарського виробництва, так і із сільськогосподарською продукцією.

Так, сільськогосподарське виробництво має такі специфічні риси, які впливають не тільки на ринкову ситуацію, функціонування аграрного ринку, а й на формування комплексу експортного маркетингу. Зокрема, серед них такі:

1. Переплетення виробничо-економічних процесів із природно-біологічними. Існують природні закони розвитку рослин і тварин, враховувати які необхідно. Тому природно-біологічний фактор є головним у визначенні ефективності сільськогосподарського виробництва, виборі технологій. Під нього підлаштовується весь комплекс сільськогосподарського виробництва, комплекти машин, хімічні засоби захисту рослин, добрива, організація праці тощо.

2. Сезонність сільського господарства, що обумовлює нерівномірне використання робочої сили і техніки, багатьох матеріальних ресурсів, а також нерівномірне надходження доходів. У зв'язку із сезонністю сільськогосподарського виробництва маркетологам необхідно не тільки збільшувати обсяги продажів врожаю в сезон, але і вживати заходів щодо збереження його протягом усього періоду споживання.

3. Тривалість виробничого циклу. Рослини і тварини ростуть порівняно повільно. Прискорити цей процес практично неможливо, як і збільшити кількість телят, поросят, курей. Розбіжність періоду виробництва і споживання ставить перед маркетологами задачу правильного прогнозування попиту покупців.

4. Залежність від погодних умов. Сільськогосподарське виробництво безпосередньо залежить від погодних умов, управляти якими людство поки не навчилося. Тому неминучі коливання врожайності та валового збору призводять до змін обсягів пропонованої на ринку сільськогосподарської продукції і, відповідно, доходів і прибутку.

5. Виробництво життєво важливих продуктів. Продукція сільського господарства відноситься до категорії продукції першої необхідності, що швидко псується, тому одним із завдань маркетологів $є$ задоволення потреб споживачів у потрібній кількості й у найкоротші терміни

6. Відмінності в родючості землі. Родючість землі по регіонах навіть по окремих господарствах істотно відрізняється, тому однакові витрати праці капіталу на різних ділянках дають різні фінансові результати. Виникають проблеми земельної ренти і регулювання доходів, дотацій окремих регіонів. Зважаючи на продуктивність грунту, природні умови маркетологам необхідно визначити обсяг, асортимент і якість продукції. 
ГАЛУЗЕВИЙ АСПЕКТ РОЗВИТКУ НАЦІОНАЛЬНОГО ГОСПОДАРСТВА

7. Розгалужений і багаторівневий характер системи сільськогосподарського маркетингу, оскільки вона включає в себе виробництво, переробку й реалізацію продукції. При цьому багаторівневий характер системи маркетинг передбачає, що недоліки і помилки одного рівня призводять до зниження ефективності системи маркетингу загалом.

Зазначені особливості необхідно враховувати при організації маркетингової діяльності в агробізнесі за всіма елементами комплексу маркетингу.

При виборі іноземного ринку для експорту своєї продукції необхідно враховувати ряд важливих моментів. Перше, необхідність на цьому ринку продукту даного підприємства. Наприклад, попит прибалтійських країн на мед досить низький, тому експорт українського меду там може не знайти свого покупця, а ринок Німеччини навпаки привабливий для експортерів, там мед має величезну популярність.

По-друге, вивчення законодавчої бази ймовірних країн-імпортерів. У деяких країнах існують преференції для України і вийти на такий ринок не складно. Але є держави, які захищають національного виробника, тому створюють складні сертифікаційні умови для експортерів. Наприклад, в африканських країнах своя особливість - високий рівень корупції, до того ж постачальників можуть просто пограбувати по дорозі до замовника. Тому компанії-експортери відправляють своїх представників за 2-3 місяці до планованої поставки, щоб вони вивчили ситуацію і ризики можливої співпраці, а також налагодили зв'язки.

Візьмемо для прикладу, ринок Китаю, який є одним із найскладніших для експорту, але водночас і найперспективнішим. Сьогодні саме КНР споживає майже третину світового виробництва м'яса. А ще в 2011 р. Китай вийшов на перше місце за обсягом споживання продуктів харчування, випередивши США. Зростання доходів китайських споживачів сприяє тому, що вони звертають увагу на імпортні продукти. Крім того, в Китаї набирає популярність тренд здорової та якісної їжі. Складнощі виходу на цей ринок полягають в серйозної конкуренції, непростих умовах сертифікації та маркування, а також місцевими особливостями маркетингу. До останніх відноситься те, що бренд при перекладі на китайську мову повинен легко читатися, вимовлятися і запам'ятовуватися. Тому необхідна адаптація назви (для прикладу, бренд "Sprite" при адаптації для китайського ринку звучить як "смарагдовий лід").

Враховуючи загальносвітовий тренд щодо здорового харчування, можна зробити висновок, що при правильному організаційному підході екологічно чиста українська продукція може мати успіх на іноземних ринках. Одним з інструментів для просування товарів $\epsilon$ шоу-руми в міжнародних центрах імпортних продуктів харчування. Вони можуть використовуватися не тільки для залучення дистриб'юторів, але і для роздрібної торгівлі. Такі торгові центри добре рекламуються, і іноземні споживачі цілеспрямовано йдуть туди за імпортними товарами. Отже, експортний маркетинг для аграрних підприємств - окремий напрямок, що має свою специфіку.

Зовнішньоекономічна діяльність відіграє дуже важливу роль в економіці нашої країни, зокрема, за підрахунками Державної служби статистики та науковців Інституту аграрної економіки, саме операції з експорту продукції аграрних підприємств. Охарактеризувати цей вид діяльності, на нашу думку, доцільно, проаналізувавши потенціал експортного маркетингу в аграрному секторі за такими показниками як:

1) динаміка обсягів українського експорту;

2) вартісна структура експорту аграрних підприємств;

3) динаміка товарної структури експорту аграрних підприємств;

4) основні імпортери вітчизняної продукції аграрних підприємств.

Так, основними сільськогосподарськими культурами, що роблять Україну одним із світових лідерів-експортерів, є зернові та кормові культури, зокрема пшениця, кукурудза, ячмінь, соняшник, цукровий буряк. Середня врожайність зернових у 2018 р. стано- 
вила 47,4 ц/га, а у 2019 р. - 49,1 ц/га, тобто підвищилася на 2,2 ц/га. У структурі експорту сільське господарство також відіграє значну роль: у 2019 р. аграрні підприємства принесли Україні майже 40 \% валютної виручки, демонструючи стабільність протягом останніх трьох років. Так, за у 2019 р. вітчизняними аграрними підприємствами було експортовано близько 50 млн тонн зернових, зернобобових (з продуктами їх переробки) та борошна. Тобто значну роль в економіці нашої країни відіграє потенціал експортного маркетингу аграрного сектору.

Державною службою статистики для аналізу експортно-імпортних операцій використовується Українська класифікація товарів зовнішньоекономічної діяльності, згідно якої продукція аграрних підприємств поділяється на чотири види: 1) живі тварини, продукти тваринного походження; 2) продукти рослинного походження; 3) жири та олії тваринного або рослинного походження; 4) готові харчові продукти.

За даними щомісячного моніторингу аграрної торгівлі, який здійснює Свропейська Комісія, за період з листопада 2018 р. по жовтень 2019 р. Україна посіла третє місце в переліку найбільших постачальників продукції аграрного сектору до країн Євросоюзу, експортувавши на суму 7,3 млрд євро. Також значний вплив на експорт аграрної продукції в ЄС вплинуло підписання Угоди про асоціацію між Україною та СС та імплементація Угоди про поглиблену та всеосяжну зону вільної торгівлі з СС (ПВЗСТ) з моменту підписання Угоди експорт аграрної продукції в СС збільшився більш ніж на третину на 6,6 млрд млрд дол. США за 11 місяців 2019 р. (з 4,5 млрд дол. США в 2013 р. до 6,1 млрд дол. США в 2018 р., що становить 37 \%) [6].

Основою зовнішньої торгівлі України у 2019 році залишалася продукція аграрних підприємств. У загальних обсягах українського експорту частка продукції аграрних підприємств становила 44,3 \%, тобто 22,2 млрд дол. США (рис. 2) [7].

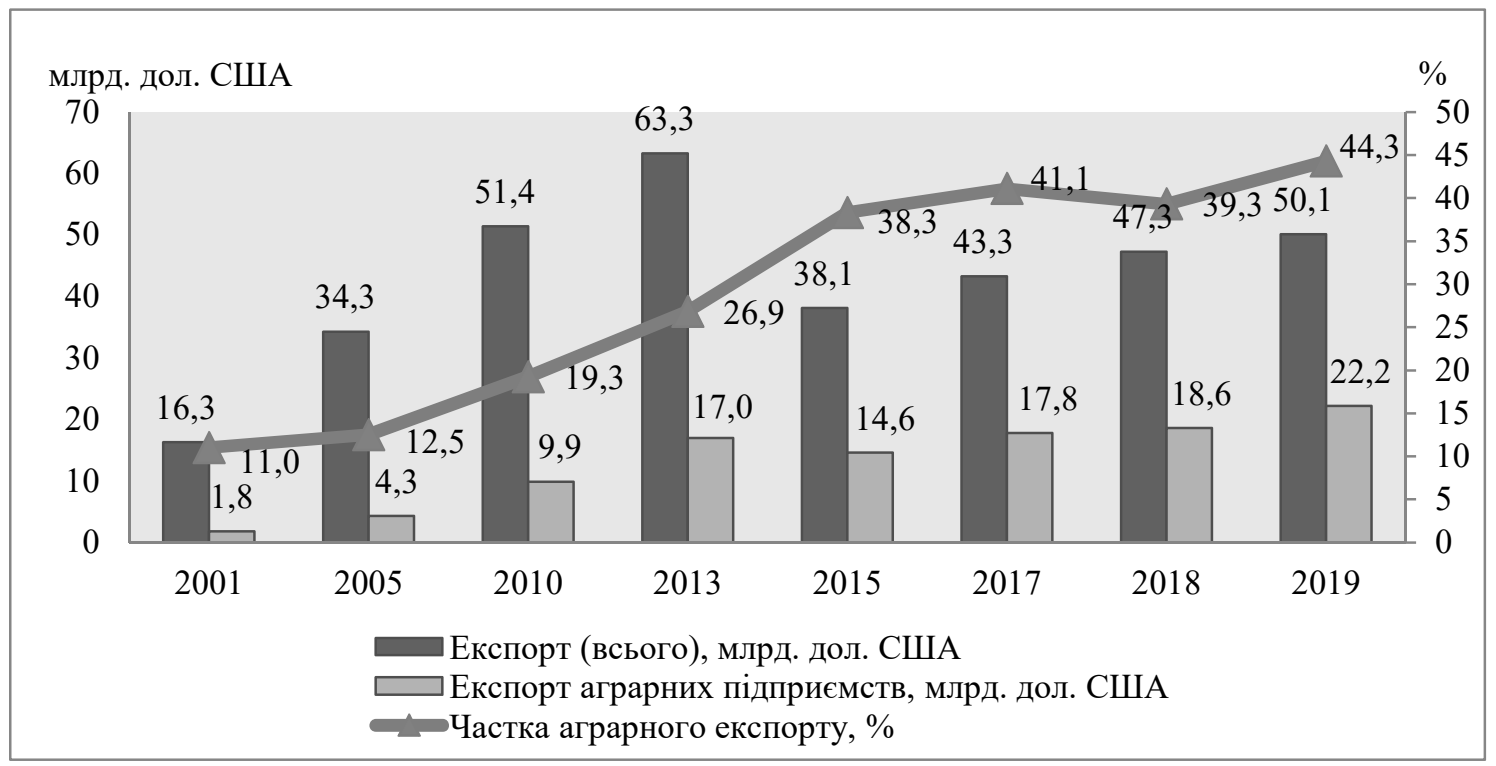

Рис. 2. Динаміка обсягів украӥнського експорту у 2001-2019 рр.

3 рис. 2 бачимо, що якщо порівнювати з попереднім 2018 р. обсяги експорту продукції аграрних підприємств збільшилися на $19 \%$, у той час як загальний експорт товарів 3 України збільшився на $6 \%$.

У структурі експорту аграрних підприємств України провідну роль відіграє продукція рослинництва (iї частка становить $58 \%$, або 12,9 млрд дол. США), зокрема це зернові культури: пшениця, кукурудза та ячмінь - 9,6 млрд дол. США (частка в загальній структурі - $43 \%$, серед зернових - $74 \%$ ), а також насіння та плоди олійних культур: соєвих бобів та насіння ріпаку - 2,6 млрд дол. США (частка становить 12 і 20 \% відповідно), 
ГАЛУЗЕВИЙ АСПЕКТ РОЗВИТКУ НАЦІОНАЛЬНОГО ГОСПОДАРСТВА

$3 \%$, або 0,7 млрд дол. США припадає на інші продукти рослинного походження. Жири та олії рослинні (переважно олія соняшникова) становлять $21 \%$ експорту аграрних підприємств (4,7 млрд дол. США), а готові харчові продукти (борошно, цукор, спирт, тютюнові вироби тощо) становлять 14 \% їхнього експорту (3,2 млрд дол. США) (рис. 3) [7].

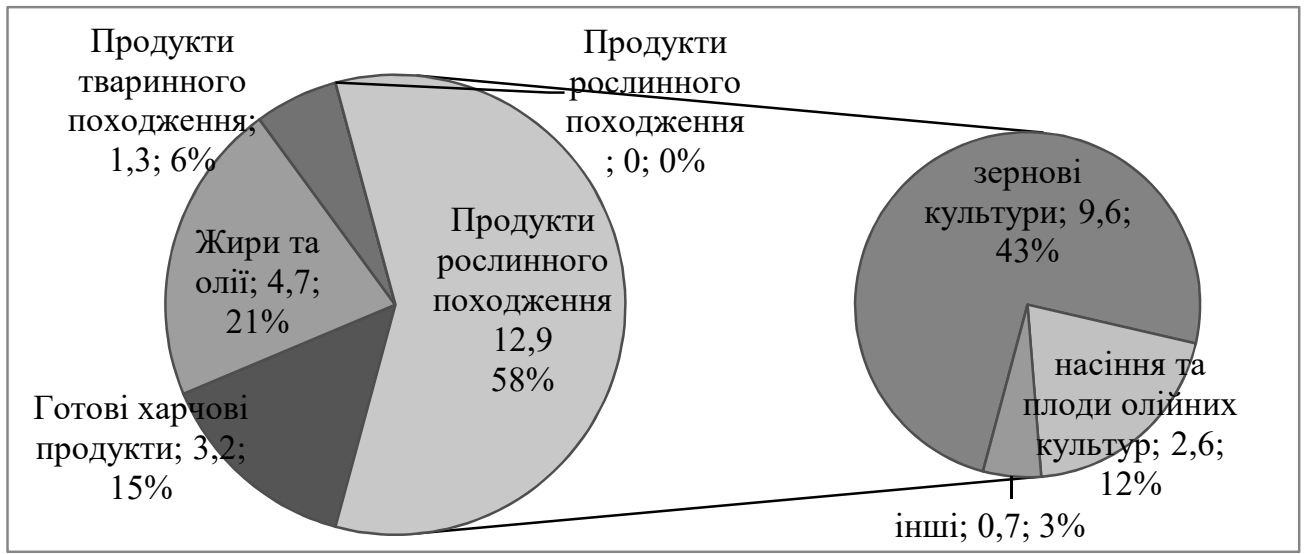

Рис. 3. Вартісна структура експорту аграрних підприємств у 2019 р., млрд дол. США

Проаналізувавши динаміку товарної структури експорту аграрних підприємств у 2010-2019 рр., приходимо до висновку, що протягом всього періоду загальні тенденції зберігаються: найбільшу питому вагу в товарній структурі займають продукти рослинного походження - у 2019 р. 12914,5 млн дол. США, або 58,3 \%, наступні в цьому ранзі жири та олії тваринного або рослинного походження - 4732,3 млн дол. США, або 21,4 \% у 2019 р.; далі готові харчові продукти - 3220,4 млн дол. США, або 14,5 \% у 2019 р.; найменшу питому вагу мають живі тварини; продукти тваринного походження - 1277,0 млн дол. США, або 5,8 \% у 2019 р. (рис. 4) [8].

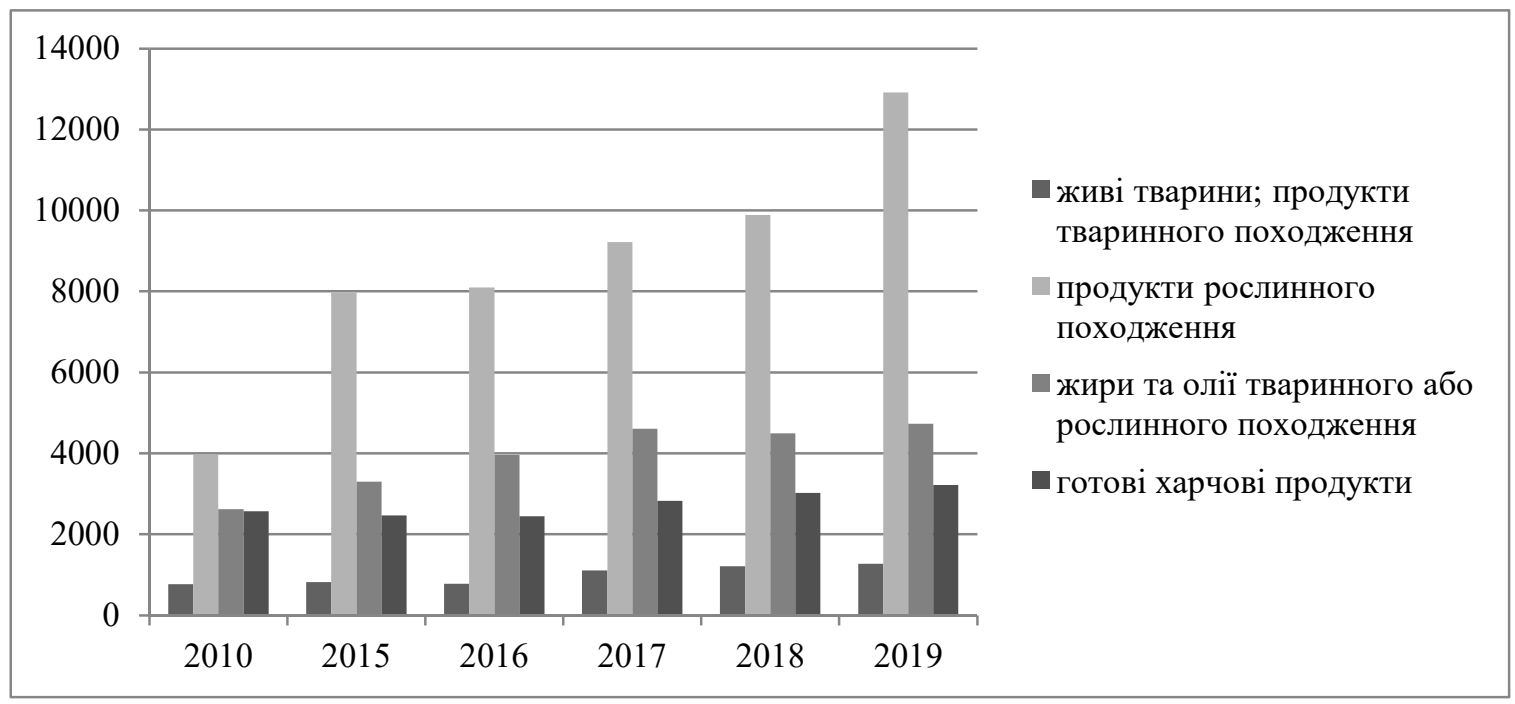

Рис. 4. Динаміка товарної структури експорту аграрних підприємств y період 2010-2019 рр., млн дол. США

Щодо товарної структури експорту аграрних підприємств, також слід зазначити, що в аналізований період зберігається тенденція не тільки відносно ранжування питомої ваги в товарній структурі, а й у розмірах питомої ваги окремих видів продукції: питома вага продуктів рослинного походження коливалася від 40,0 \% у 2010 р. до 58,3 \% у 2019 р.; питома вага жирів та олій тваринного або рослинного походження - від 21,4 \% у 2019 р. до 26,3 \% у 2010 р.; питома вага готових харчових продуктів - від 14,5 \% у 2019 р. до 25,9\% у 2010 р.; питома вага живих тварин, продуктів тваринного похо- 
дження - від 5,1 \% у 2016 р. до 7,8 \% у 2010 р. (див. табл.) [8]. Тобто за період 20102019 рр. відбулося незначне коливання у розмірах питомої ваги окремих видів продукції, експортованої аграрними підприємствами.

Таблиця

Товарна структура експорту аграрних підприємств у період 2010-2019 рр.

\begin{tabular}{|c|c|c|c|c|c|c|}
\hline \multirow{2}{*}{ Роки } & \multirow{2}{*}{$\begin{array}{c}\text { Вартість / } \\
\text { питома вага }\end{array}$} & $\begin{array}{c}\text { живі тварини; } \\
\text { продукти } \\
\text { тваринного } \\
\text { походження }\end{array}$ & $\begin{array}{c}\text { Вродукти } \\
\text { рослинного } \\
\text { походження }\end{array}$ & $\begin{array}{c}\text { жири та олії } \\
\text { тваринного } \\
\text { або рослинно- } \\
\text { го походження }\end{array}$ & $\begin{array}{c}\text { готові } \\
\text { харчові } \\
\text { продукти }\end{array}$ & Усього \\
\hline \multirow{2}{*}{2010} & млн дол. США & 771,4 & 3976,2 & 2617,3 & 2571,1 & 9936,0 \\
\cline { 2 - 7 } & \% & 7,8 & 40,0 & 26,3 & 25,9 & 100,0 \\
\hline \multirow{2}{*}{2015} & млн дол. США & 823,4 & 7971,5 & 3299,8 & 2468,4 & 14563,5 \\
\cline { 2 - 7 } & $\%$ & 5,7 & 54,7 & 22,7 & 16,9 & 100,0 \\
\hline \multirow{2}{*}{2016} & млн дол. США & 775,0 & 8093,7 & 3963,0 & 2450,1 & 15281,8 \\
\cline { 2 - 7 } & \% & 5,1 & 53,0 & 25,9 & 16,0 & 100,0 \\
\hline \multirow{2}{*}{2017} & млн дол. США & 1108,8 & 9215,7 & 4605,7 & 2826,7 & 17756,9 \\
\cline { 2 - 7 } & \% & 6,2 & 52,0 & 25,9 & 15,9 & 100,0 \\
\hline \multirow{2}{*}{2018} & млн дол. США & 1210,6 & 9886,1 & 4496,5 & 3018,6 & 18611,8 \\
\cline { 2 - 7 } & \% & 6,5 & 53,1 & 24,2 & 16,2 & 100,0 \\
\cline { 2 - 7 } & млн дол. США & 1277,0 & 12914,5 & 4732,3 & 3220,4 & 22144,2 \\
\cline { 2 - 7 } & $\%$ & 5,8 & 58,3 & 21,4 & 14,5 & 100,0 \\
\hline
\end{tabular}

Основними ринками збуту продукції українських аграрних підприємств залишаються Азія: 41,7 \% - експорту та ЄС: 34,9 \% - експорту. До основних споживачів продукції аграрних підприємств входять Китай, Єгипет, Індія, Туреччина, Нідерланди, Іспанія, Німеччина, Польща, Італія та Білорусь (рис. 5) [6].

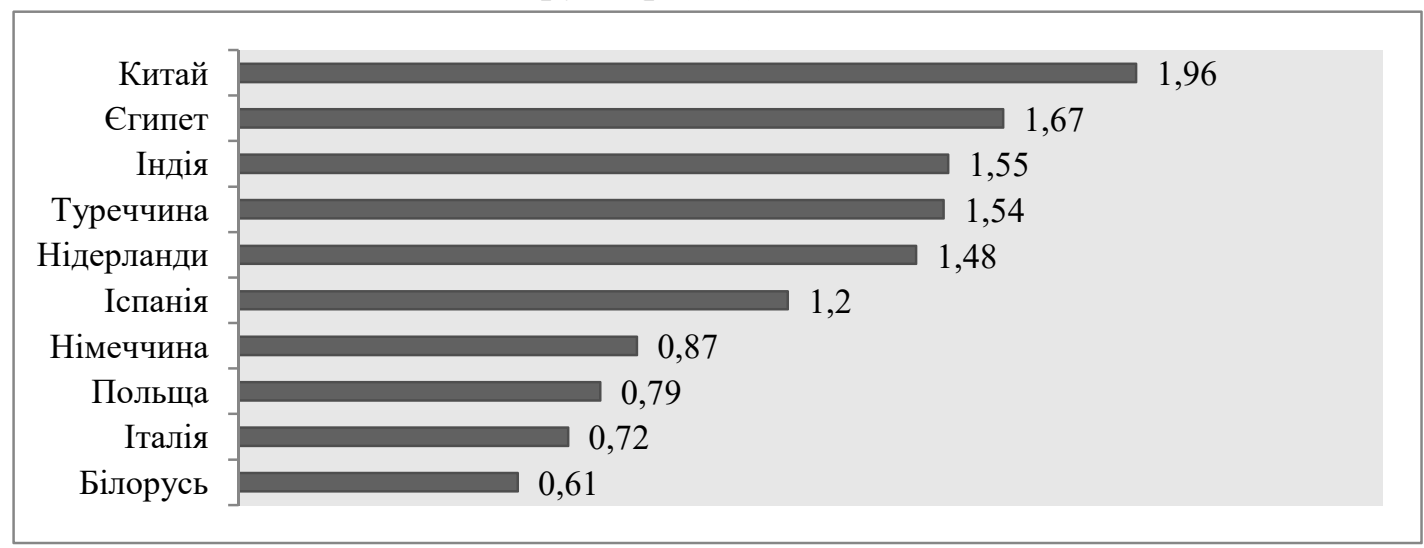

Рис. 5. Основні імпортери вітчизняної продукиії аграрних підприємств 2019 р., млрд дол. США

3 рис. 5 бачимо, що у 2019 р. рейтинг країн-імпортерів вітчизняної продукції аграрних підприємств очолив Китай, який імпортував у аграрних підприємств України продукції на 1,96 млрд дол. США. Друге місце кілька років поспіль утримує Сгипет, який придбав вітчизняних харчів на 1,67 млрд дол. США. Третє місце у рейтингу посідає Індія, яка у 2019 р. імпортувала з України аграрної продукції на 1,55 млрд дол. США. Значну виручку українські аграрні підприємства отримали також від експорту до Туреччини (1,54 млрд дол. США), Нідерландів (1,48 млрд дол. США), Іспанії (1,20 млрд дол. США), Німеччини (0,87 млрд дол. США), Польщі (0,79 млрд дол. США), Італії (0,72 млрд дол. США), Білорусі (0,61 млрд дол. США). Сумарно названі 10 країн забезпечили українським аграрним підприємствам близько 58 \% доходів від експорту продукції агропромислового комплексу. 
ГАЛУЗЕВИЙ АСПЕКТ РОЗВИТКУ НАЦІОНАЛЬНОГО ГОСПОДАРСТВА

Висновки і пропозиції. Таким чином, проаналізувавши сучасний стан потенціалу експортного маркетингу в аграрному секторі за запропонованими показниками, можемо зробити висновок, що в економіці нашої країни експорт аграрних підприємств відіграє ключову роль: у 2019 р. аграрні підприємства принесли Україні майже 40 \% валютної виручки, демонструючи стабільність протягом останніх трьох років. У 2019 р. вітчизняними аграрними підприємствами було експортовано близько 50 млн тонн зернових, зернобобових та борошна. Основою зовнішньої торгівлі України у 2019 р. залишалася продукція аграрних підприємств: у загальних обсягах українського експорту частка продукції аграрних підприємств склала 44,3 \%. Обсяги експорту продукції аграрних підприємств збільшилися на 19 \%, порівняно з попереднім 2018 р., у той час як загальний експорт товарів з України - збільшився на $6 \%$. У структурі експорту аграрних підприємств України провідну роль відіграє продукція рослинництва (iї частка становить 58 \%), зокрема це зернові культури: пшениця, кукурудза та ячмінь, а також насіння та плоди олійних культур: соєвих бобів та насіння ріпаку. Основними ринками збуту продукції українських аграрних підприємств залишаються Азія: 41,7\% - експорту та ЄС: 34,9\% експорту. До основних споживачів продукції аграрних підприємств входять Китай, Сгипет, Індія, Туреччина, Нідерланди, Іспанія, Німеччина, Польща, Італія та Білорусь. Також варто зазначити, що виникає необхідність розробки комплексу експортного маркетингу аграрних підприємств з метою підвищення його потенціалу в аграрному секторі України.

\section{Список використаних джерел}

1. Белевят О. А., Сахацький М. П., Запша Г. М. Наукові основи формування системи маркетингу в сільськогосподарських підприємствах. Економіка харчової промисловості. 2009. № 1. C. 31-34.

2. Воронецька I. С. Особливості функціонування маркетингу в агропромисловому виробництві. Збірник наукових праць ВНАУ. Серія: Економічні науки. 2011. № 2(53), т. 3. С. 93-98.

3. Бурова О. М. Особливості процесу формування системи агромаркетингу на підприємствах АПК. Таврійський науковий вісник. 2015. № 78. С. 196-201.

4. Муштай В. А., Горян Я. С. Організація раціональної системи розподілу сільськогосподарської продукції. Інфраструктура ринку. 2018. Вип. 23. С. 117-123. URL: http://www.marketinfr.od.ua/journals/2018/23_2018_ukr/22.pdf.

5. Нападовська Л. А. Системний підхід як методологічний базис планування розвитку підприємства у нестабільному середовищі. Університетські наукові записки. 2006. № 1. С. 338-344.

6. Сільське господарство в Україні. 2020. URL: https://dlf.ua/ua/silske-gospodarstvo-v-ukrayini/.

7. Статистичний щорічник України за 2019 рік / за ред. I. С. Вернера. Київ, 2020. С. 361-371. URL: http://www.ukrstat.gov.ua/druk/publicat/kat_u/2020/zb/11/zb_yearbook_2019.pdf.

8. Сільське господарство України за 2019 рік / відп. за вип. О. М. Прокопенко. Київ, 2019. C. 29. URL: http://www.ukrstat.gov.ua/druk/publicat/kat_u/2019/zb/09/Zb_sg_2018\%20.pdf.

\section{References}

1. Beleviat, O.A., Sahatsii, M.P., \& Zapsha, G.M. (2009). Naukovi osnovy formuvannia systemy marketyngu v silskogospodarskykh pidpryemstvakh [Scientific fundamentals of marketing system formation in agricultural enterprises]. Ekonomika kharchovoi promyslovosti-The economy of the food industry, 1, 31-34.

2. Voronetska, I.S. (2011). Osoblyvosti funktsionuvannia marketyngu $\mathrm{v}$ agropomislovomu vyrobnytsvi [Features of marketing functioning in agroindustrial production]. Zbirnyk naukovykh prats VNAU. Seriia: Ekonomichni nauky - Collection of scientific works of VNAU. Series: Economic Sciences, 2(53)(3), 93-98.

3. Burova, O.M. (2015). Osoblyvosti protsesu formuvannia systemy agromarketingu na pidpryemstvah APK [Features of the process of forming the agromarketing system at the enterprises of agrarian and industrial complex]. Tavriiskyi naukovyi visnyk - Taurian Scientific Bulletin, 78, 196-201.

4. Mushtai, V.A., \& Horian, YS. (2018). Organizatsiia ratsionalnoi systemy rozpodilu silskogospodarskoyi prodyktsii [Organization of a rational system of distribution of agricultural products]. Infrastruktura rynku - Market Infrastructure, 23, 117-123. http://www.market-infr.od.ua/ journals/2018/23_2018_ukr/22.pdf. 
ГАЛУЗЕВИЙ АСПЕКТ РОЗВИТКУ НАЦІОНАЛЬНОГО ГОСПОДАРСТВА

5. Napadovska, L.A. (2006). Systemnyi pifhid iak metodologichnyi basys planuvannia rozvytku pidpryemstva u nestabilnomu ceredovyschi [System approach as a methodological basis for planning enterprise development in an unstable environment]. Universytetski naukovi zapysky - University Scientific Notes, 1, 338-344.

6. Silske hospodarstvo v Ukraini 2020 [Agriculture in Ukraine 2020]. (2020). https://dlf.ua/ua/ silske-gospodarstvo-v-ukrayini/.

7. Verner, I.Ye. (Ed.). (2020). Statystychnyi shchorichnyk Ukrainy za 2019 rik [Statistical Yearbook of Ukraine for 2019]. (2020). http://www.ukrstat.gov.ua/druk/publicat/kat_u/2020 /zb/11/zb_yearbook_2019.pdf.

8. Prokopenko, O.M. (Ed.) (2019). Silske hospodarstvo Ukrainy za 2019 rik [Agriculture of Ukraine for 2019]. (2019). http://www.ukrstat.gov.ua/druk/publicat/kat_u/2019/zb/09/Zb_sg_2018\%20.pdf.

Турчин Люба Ярославівна - кандидат економічних наук, доцент, доцент кафедри підприємництва і торгівлі,

Західноукраїнський національний університет (вул. Львівська, 11, м. Тернопіль, 46009, Україна).

Turchyn Liuba - PhD in Economics, Associate Professor. Associate Professor of Department for Entrepreneurship

and Trade, West Ukrainian National University (11 Lvivska Str., 46009 Ternopil, Ukraine).

E-mail: 0963104024L@gmail.com

ORCID: https://orcid.org/0000-0001-6238-1812

Турчин Л. Потенціал експортного маркетингу в аграрному секторі України. Проблеми і перспективи економіки та управління. 2021. № 2(26). C. 65-74. 